\title{
Energy scenario and biofuel policies and targets in ASEAN countries
}

\author{
M. Mofijur ${ }^{\text {a,*, H.H. Masjuki }}{ }^{\text {b }}$, M.A. Kalam ${ }^{\text {b }}$, S.M. Ashrafur Rahman ${ }^{\text {b }}$, H.M. Mahmudul ${ }^{\text {c }}$
}

a School of Engineering \& Technology, Central Queensland University, Rockhampton 4701, QLD, Australia

b Department of Mechanical Engineering, University of Malaya, 50603 Kuala Lumpur, Malaysia

'Department of Mechanical Engineering, University Malaysia Pahang, 25000 Kuantan, Malaysia

\section{A R T I C L E I N F O}

\section{Article history:}

Received 23 June 2014

Received in revised form

9 December 2014

Accepted 7 February 2015

Available online 3 March 2015

Keywords:

Global energy

Biofuel development

Policy

Engine performance and emission
A B S T R A C T

Present energy situation of the world is unsustainable due to unequal geographical distribution of natural wealth as well as environmental, geopolitical and economical concerns. Ever increasing drift of energy consumption due to growth of population, transportation and luxurious lifestyle has motivated researchers to carry out research on biofuel as a sustainable alternative fuel for diesel engine. Biofuel such as biodiesel and ethanol, produced from renewable feedstock's, are the most appropriate alternative of petroleum fuels. Government of many countries has set a target to use biofuel in transportation and industrial sectors to reduce the fossil fuel demand in their countries. This report compiled the findings on global energy scenario, potential of biofuel as a renewable energy source, biofuel policy and target of some selected countries and the effect of mixed blends of biofuel and diese on engine performance and emission parameters of a diesel engine. The study concluded that the energy consumption and $\mathrm{CO}_{2}$ emissions in ASEAN countries increasing day by day. To reduce the energy consumption and harmful gasses emission to the environment, government of ASEAN countries have set target to use biofuel in diesel engines as biofuel-diesel blend have potential to reduce dependency on fossil fuel as well as the exhaust emissions of the engine.

Contents

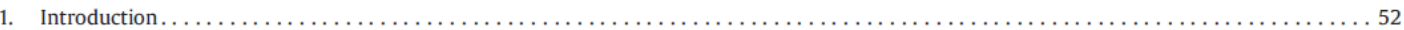

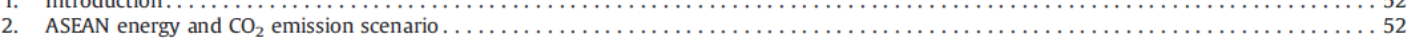

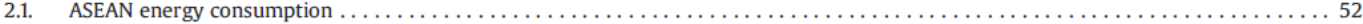

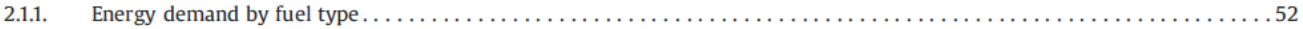

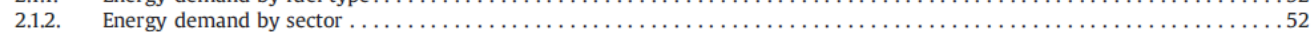

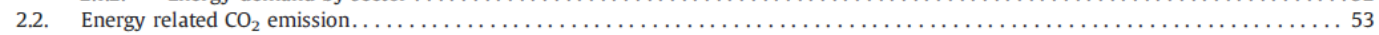

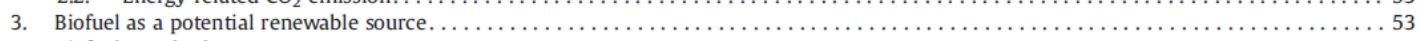

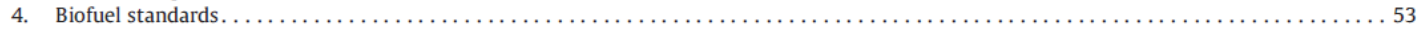

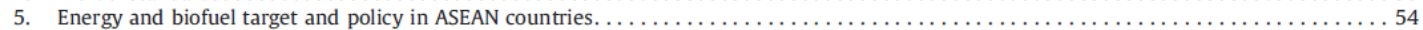

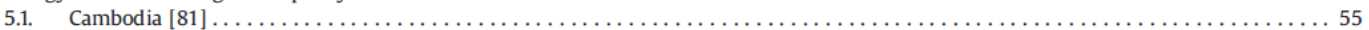

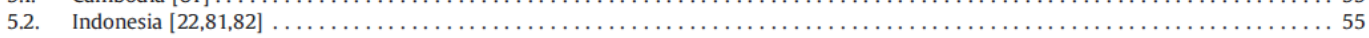

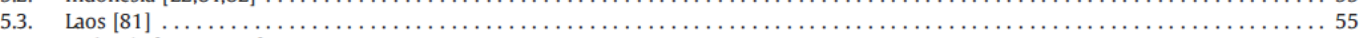

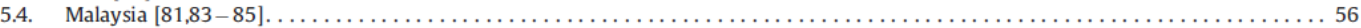

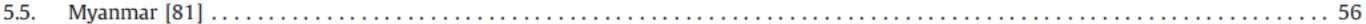

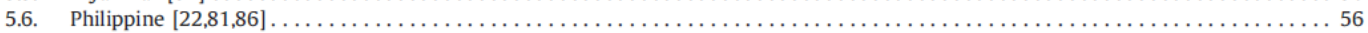

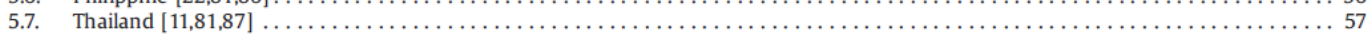

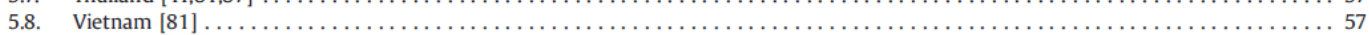

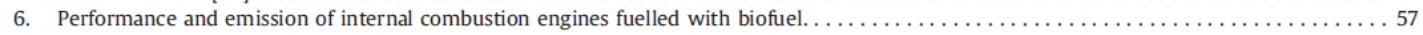

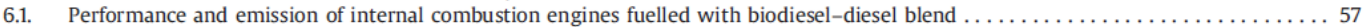

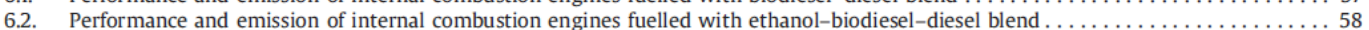

\footnotetext{
* Corresponding author: Tel: +61 749309634

E-mail address: m.rahman@cqu.edu.au (M. Mofijur).
}

http://dx.doi.org/10.1016/j.rser.2015.02.020

1364-0321/० 2015 Elsevier Ltd. All rights reserved. 


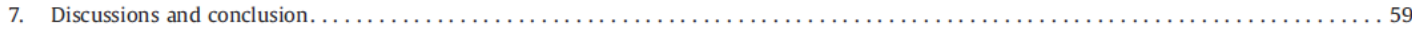

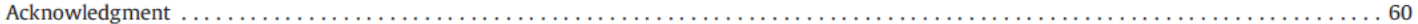

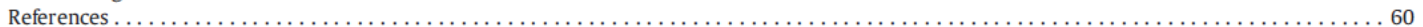

\section{Introduction}

Fossil fuels are widely used as a transportation and machinery energy sources due to its high heating power, availability and combustion properties but its reserve is depleting day by day [1-3]. Today diesel-powered vehicles represent about one-third of the vehicles sold in Europe and the United States and it is being predicted that the sales of diesel run automotive will rise from $4 \%$ in 2004 to $11 \%$ by 2012 [4]. However, emission produced by burning of petroleum derived fuel has a serious effect on both the environment and human health [5-9]. Every year more than 15 billion tons of $\mathrm{CO}_{2}$ is added to earth's atmosphere. The combustion of fossil fuels is a big contributor to the increase in the level of $\mathrm{CO}_{2}$ in the atmosphere which is directly associated with global warming [10-13]. As an alternative to petro diesel in the transportation sector, biofuel development has potentials in addressing issues related to energy and food security, climate change, and rural development. First, biofuels can be regarded as integral part of emerging bio-economy and exhibiting increasing potential to substitute materials including fuels from fossil oil in the near future. Second, as a renewable energy, biofuels are derived from plant materials which can contribute to the reduction of greenhouse gases (GHG) emissions when replacing fossil oil if they are sustainably managed [14-17]. Third, biofuels production is often associated with farmers in rural and/or poor areas. It has the potential to produce new incomes for farmers while generating new jobs and new businesses to alleviate poverty and improve farmers' life standards [18]. Agricultural biomass is a relatively broad category of biomass that includes the food based portion (oil and simple carbohydrates) of crops (such as corn, sugarcane, beets) and the non-food based portion (complex carbohydrates) of crops (such as the leaves, stalks, and cobs of corn stover, orchard trimmings, rice husk, straw), perennial grasses, and animal waste [19].

To ensure the sustainability of biofuels, different regions including the European Union, the Unites States and other countries are developing their national strategies on biofuel development $[20,21]$. The United States National Biofuel Action Plan has covered the whole chain of the biofuel production process, including feedstock production and logistics, conversion technologies, distribution and end use while at the same time, addressing the biofuel sustainability issues. New regulations on biofuels are, however, under-developed [22]. The EU sets out seven strategic policy areas for the production and use of biofuels, including measures of stimulating demand for biofuels, ensuring environmental benefits, developing the production and distribution of biofuels, expanding feedstock supplies, enhancing the trade opportunities of biofuels, supporting developing countries, as well as supporting research and innovation activities. In 2010 worldwide biofuel production reached 105 billion liters (28 billion gallons US), increasing almost by one-sixth from that of 2009 . Biofuels met nearly $2.7 \%$ of the global fuel demand for road transport. This contribution was largely made up of ethanol and biodiesel [23].

Although there are large number of literatures to research on engine performances and its emissions when using biodiesels, especially in last decades, only fewer people have analyzed an reviewed them. This paper intends to summarize the different production systems of biofuels, current status of application of biofuels and their future perspective in ASEAN countries.

\section{ASEAN energy and $\mathrm{CO}_{2}$ emission scenario}

\subsection{ASEAN energy consumption}

Global energy consumption is growing every day [24,25]. In 2011, the total primary energy consumption of ASEAN was equivalent to Japan's, which is around 444 Mtoe [26]. It is predicted that, in 2040, ASEAN energy consumption will rise to 1186 Mtoe, rising at an annual rate of $3.1 \%$. Indonesia will surplus Japan's energy consumption in 2035 and it is predicted that they will become 5th largest energy consumer of the world. However, as Malaysia and Thailand population growth will decelerate from 2025, their primary energy consumption rate will be slower than other ASEAN countries (Fig. 1).

In the last few years, industries facing problem of hiking labor cost and earning less profit has shifted their operation to Myanmar and other neighboring countries from Malaysia and Thailand. As a result, primary energy consumption of Myanmar will increase almost 2.5 times in the next 30 years.

\subsubsection{Energy demand by fuel type}

ASEAN countries are heavily dependent upon fossil fuel. The demand is projected to rise from $76 \%$ in 2011 to $80 \%$ in 2035 [27]. Compared to 2011 , oil demand will rise by $25.6 \%$ and $58.1 \%$ annually per annum in 2020 and 2035 . However, there total share will drop to $31 \%$ from $38 \%$. Coal demand increases three fold during this time period, increasing at a rate of $4.8 \%$ per year. In 2035 , it will have the second largest market share of $28 \%$ overtaking natural gas. Due to higher gas prices, the gas demand growth will be slower compared to other sources. The market share of natural gas will remain almost same during this time period, at just over $20 \%$. However, introduction of more strict pollution regulation might boost the prospects of natural gas.

\subsubsection{Energy demand by sector}

Energy demand in the buildings sector increases by $1.8 \%$ year, which results in more than $50 \%$ overall increase during the time period [27]. Whereas, global energy demand for building sectors increases with an average annual growth rate of $1.6 \%$ per year [28]. World energy consumption in the transportation sector increases

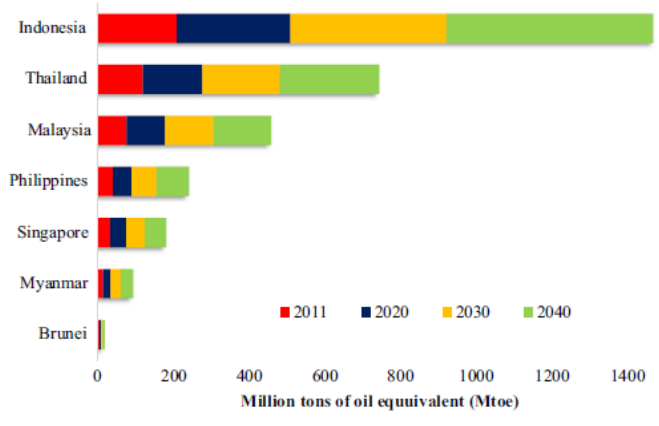

Fig. 1. ASEAN primary energy consumption (2011-2040). 
by an average of $1.1 \%$ per year [28], whereas energy demand for transportation sector in ASEAN increases at a rate of $2.7 \%$ per year [27]. The rapid increase in transportation sector might be due to increase in income of people, low or subsidized oil price, and inadequate public transport. However, despite strong growth, compared to world average, passenger light duty vehicle ownerships rose to 71 person out of 1000 in 2035 from 40 persons per 1000 in 2011 [27]. Most of the growth were seen in Indonesia, Malaysia, Thailand and the Philippines. Energy demanded by industrial sector was the highest both in 2011 and in 2035, rising from 120 Mtoe to 225 Mtoe (Fig. 2).

\subsection{Energy related $\mathrm{CO}_{2}$ emission}

Liaquat et al. [29] reported that if the average global temperature is increased by more than $2{ }^{\circ} \mathrm{C}$, many people about hundreds of millions of people will lose their lives [30]. Energy-related carbon dioxide emissions - those emissions produced through the combustion of liquid fuels, natural gas, and coal - account for much of the world's anthropogenic greenhouse gas emissions. As a result, energy consumption is an important component of the global climate change debate. Energy related $\mathrm{CO}_{2}$ emission of ASEAN increased to $2.3 \mathrm{Gt}$ (gigatonnes) in 2035 from $1.2 \mathrm{GT}$ in 2011 , which is $6.1 \%$ of global emission [27]. This is mainly due to the rapid increase in fossil fuel use throughout the time period (Fig. 3).

\section{Biofuel as a potential renewable source}

Biofuel is the environment friendly and renewable source of alternative fuel which is mainly produced from animal fats (tallow, lard, white or yellow grease, poultry fats, or fish oils); recycled greases (used cooking and frying oils); and most commonly, plant oils (from soybeans, corn, rapeseed, sunflowers, and cottonseeds, etc.) $[25,30-33]$.

To use this biofuel in diesel engine there is no need for engine modification as well [34]. In general, the term biofuel is used to represent all the liquid and gaseous transportation fuels derived predominantly from biomass [35]. Biofuels conversion system is one of the important steps in the whole biofuel production chain. Factors such as high yields and low energy consumption are important to consider in promoting the future competitiveness of biofuels to fossil fuels in the market. The biofuel production process is shown in Fig. 4. Biofuels can be derived from any biological carbon into biofuel via different production pathways to produce source, but photosynthetic plants are the most biodiesel,

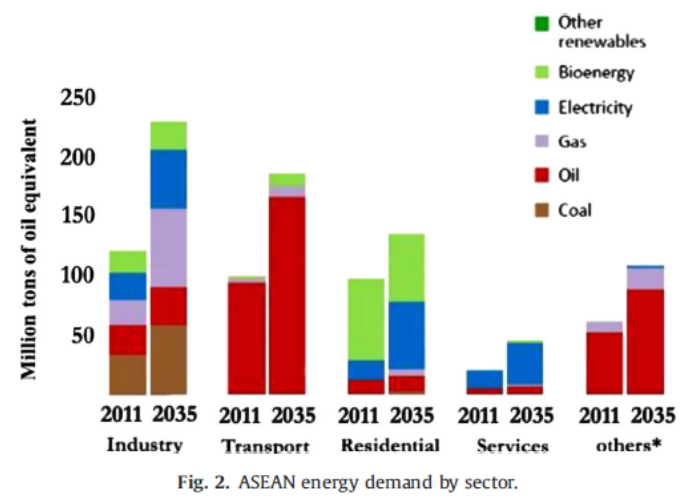

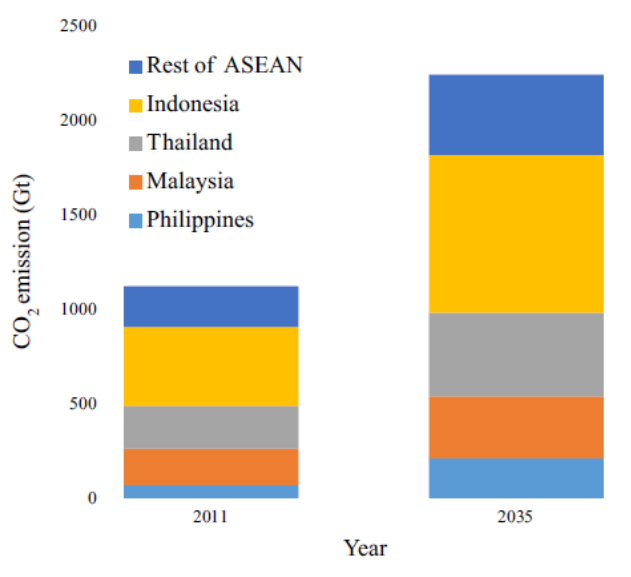

Fig. 3. Energy related $\mathrm{CO}_{2}$ emission of ASEAN.

ethanol, butanol, methane, or other fuels; all are commonly used feedstock. Biofuels are categorized the subject of ongoing research. Technologies to produce into first-generation biofuel and advanced biofuel (second-first-generation fuels are mature but some feedstocks are generation, third-generation, etc.). Currently, biodiesel and bioethanol are the two most promising biofuel being projected to replace conventional fossil fuels in transportation. Biodiesel or fatty acid methyl ester (FAME) is normally synthesized through transesterification of vegetable oils with methanol and the aid of appropriate catalysts. It can be used to replace mineral diesel in compression-ignition $(\mathrm{CI})$ engine which has almost similar properties without requiring any major engines modifications [36-38]. Commercial production of biodiesel has been well established and is available to be purchased as turn-key plants in many countries [39]. On the other hand, bioethanol is suitable to replace the usage of gasoline in petrol engine. Conventional bioethanol is produced from the fermentation of simple sugar or starch crops. Its large-scale production has been well proven and demonstrated successfully in Brazil [40]. However, it competes with food sources for human consumption which renders it susceptible to criticisms. Another alternative raw material for bioethanol production is using inedible food sources mainly lignocellulosic material such as forest and agricultural biomass waste. However, additional pretreatment steps are normally required which will increase the overall production cost. Process optimization is still being researched intensively at pilot plant scale in order to find a more cost-effective production method for mass commercialization [41].

Biofuels have several advantages over conventional fuels diesel and gasoline. On the other hand, there are also some disadvantages of using biofuels. The advantages and disadvantages of biofuel are discussed in the following Table 1.

\section{Biofuel standards}

Quality standards for producing, marketing and storing of biofuel are being developed and implemented around the world in order to maintain the end product quality and also to ensure consumers' confidence. First, Austria have defined and approved the standards for biodiesel from rapeseed oil as a petro diesel fuel. At present the US and EU standards are the most referred standards followed by standards from other biofuel producing 


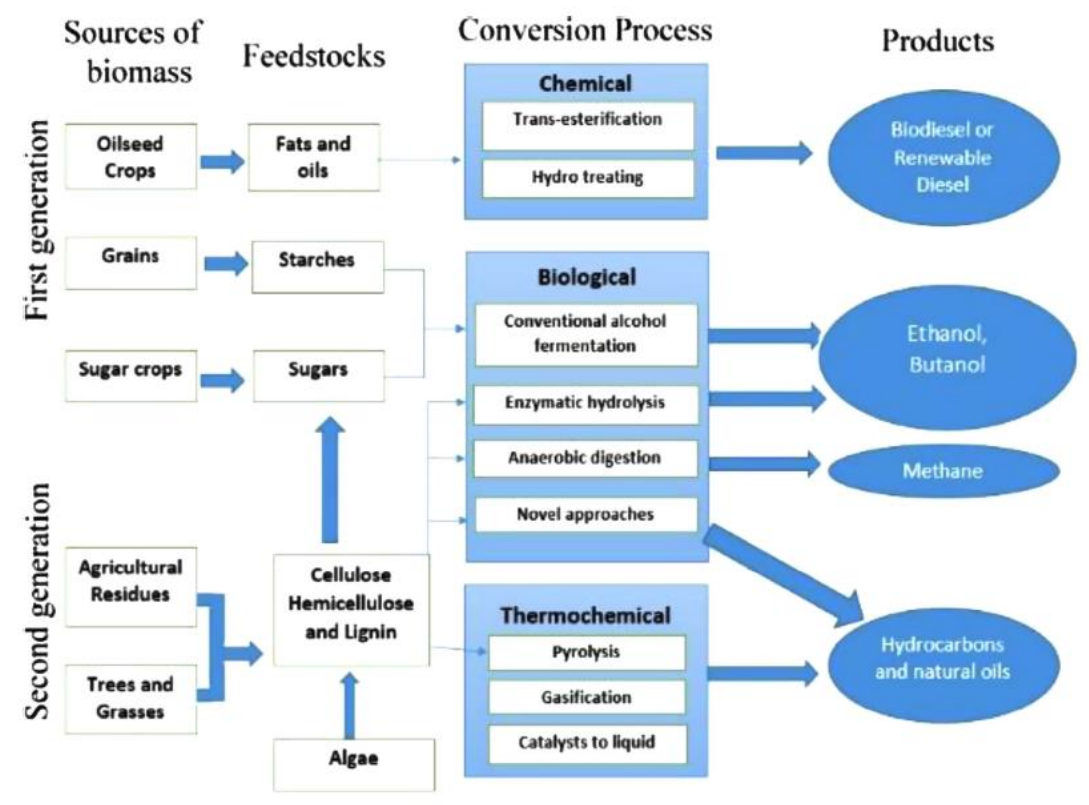

Third generation

Fig. 4. The biofuel production process.

Table 1

Advantages and disadvantages of biofuels [42-74]

\begin{tabular}{|c|c|c|}
\hline Fuel & Advantages & Disadvantages \\
\hline \multirow{5}{*}{ Biodiesel } & $\begin{array}{l}\text { Contains } 10-11 \% \text { more oxygen which ensures better } \\
\text { combustion characteristics }\end{array}$ & $\begin{array}{l}\text { Contains almost } 12 \% \text { lower energy content than diesel, which leads to increase in fue } \\
\text { consumption }\end{array}$ \\
\hline & Has better lubricity properties & $\begin{array}{l}\text { Transesterification has some environmental effects such as waste disposal and water } \\
\text { requirement for washing, soap formation, etc. }\end{array}$ \\
\hline & Higher yield in oil extraction & Higher costs for establishment and operation of production plants \\
\hline & Up to $20 \%$ biodiesel blends no engine modification needed & \\
\hline & Serves as climatic neutral in view of the climatic change & \\
\hline \multirow[t]{5}{*}{ Bio-ethanol } & Has high octane number & Energy content of ethanol is lower \\
\hline & Increases thermal efficiency & Lower vapor pressure of ethanol can contribute to produce unregulated pollutants \\
\hline & Increases engine torque output & Can enhance corrosion on ferrous components such as fuel tank \\
\hline & Allows the use of high compression ratio without knocking & Results in higher gas heat capacity and lower combustion gas temperature \\
\hline & Produce cleaner emission & Low vapor pressure of ethanol makes starting cold engine difficult \\
\hline
\end{tabular}

nations [18,42]. A comparison of biodiesel standards of two ASEAN countries (Malaysia and Indonesia) and other major countries around the world is shown in Table 2.

\section{Energy and biofuel target and policy in ASEAN countries}

Biofuel production has been rising drastically in many Asian countries in recent years. This is driven primarily by the government's pursuit of energy security, economic development (particularly, improvement of trade balances and expansion of the agriculture sector), and poverty alleviation. Most Asian countries have their biofuel strategies focused around the country's main agricultural product and new business opportunities. Form the policies of ASEAN countries it can be easily comprehended that, they are mainly focused on export rather than utilization in their own countries and less concern about environment. All these countries pay heavy subsidies on petroleum transport fuel which 
Table 2

Comparison of biofuel standards around the world [18,42,75,76].

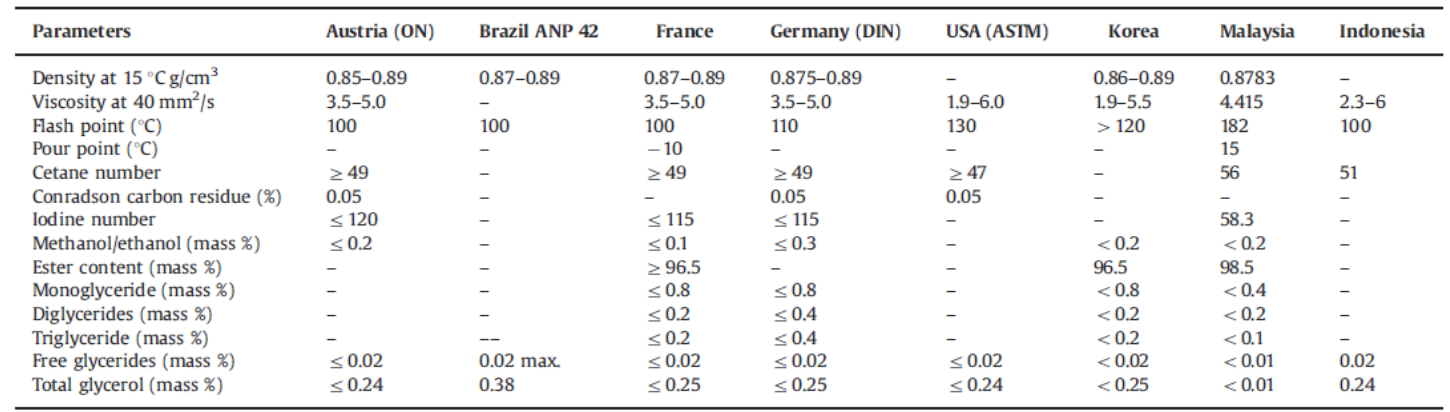

Table 3

Target to promote biofuel in some countries in the world [78-80].

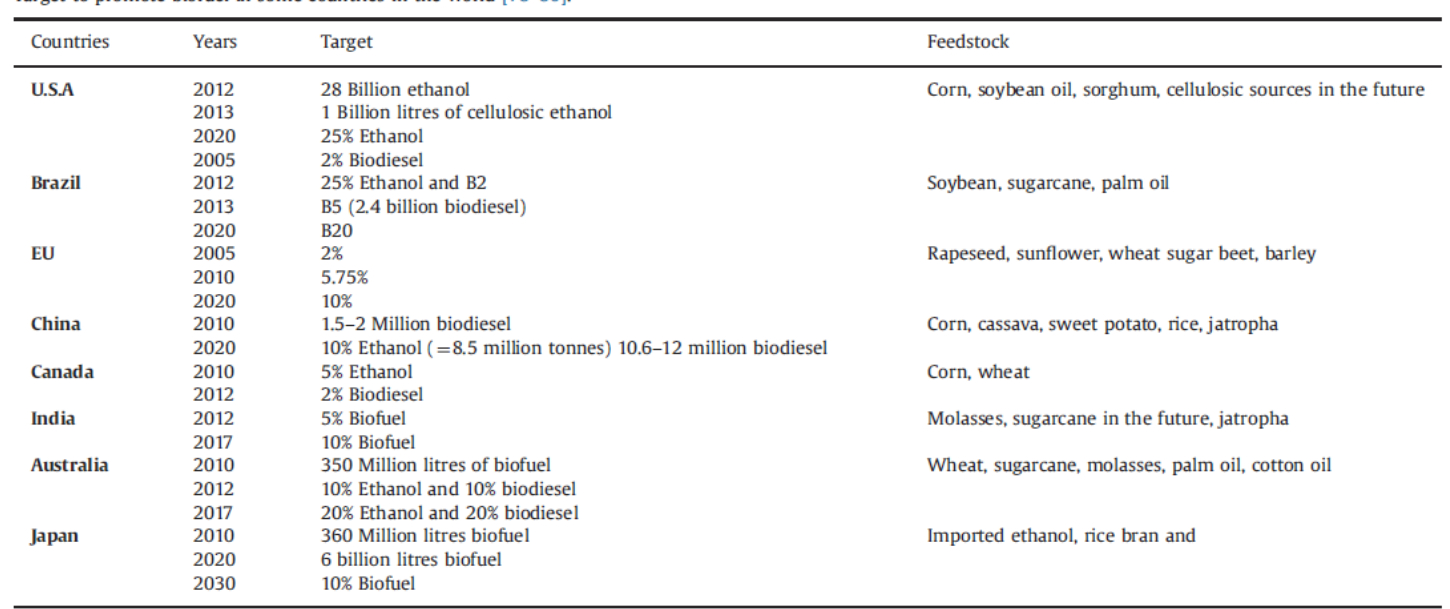

are imported. On the other hand, to commercialize self-produced biofuel they need to pay more subsidies as biofuel price is still a bit higher [77]. Table 3 shows biofuel target of some countries in the world

\subsection{Cambodia [81]}

Master Plan on Renewable Energy (RE)

a) Study of policy to promote electrification.

b) Introduce of RE.

c) Study of Institutional and organization for sustainable operation and maintenance support by the appropriate business model include financial procurement plan.

\subsection{Indonesia $[22,81,82]$}

1. Supply and Utilization of Biofuels as Alternative Energy (Presidential Instruction No. 1 year 2006):

- facilitate the supply of crops of Biofuel raw material;

- conduct extension of the development of crops of biofuel raw materials;
- facilitate the supply of high yielding clone seeds; and

- Integrate activities of development and post-harvest.

2. National Energy Policy (Presidential Decree No. 5 year 2006):

- RE 17\%; $5 \%$ biofuel in the energy mix by 2025

3. Energy Law No. 30 (10 July 2007)

- Attention on new energy development.

- Increase usage of new renewable energy by government and local government.

- Incentives from government and local government until it reach economic development stage.

4. Biofuel Mandatory (Energy and Mineral Resources Minister Regulation No. 32, 2008):

- Bioethanol: 1\% (2009)-15\% (2025);

- Biodiesel: 1\% (2008)-20\% (2025).

5.3. Laos [81]

a) Ministry of Energy \& Mines

- Energy.

- Electricity sector development.

b) Ministry of Industry \& Commerce

- Petroleum products trading.

c) National Administration of Science \& Technology 
- Renewable research

d) Ministry of Agriculture \& Forestry

- Biofuel feedstock.

e) Ministry of Energy \& Mines: drafted Energy Policy \& Biofuel Policy

f) Prime Minister Office: drafted biofuel initiatives focused on Jatropha

g) National Administration of Science \& Technology: R\&D on Bioenergy Project

- Luang Prabang Province: cultivation of Jatropha \& stone Jatropha.

- Ministry of Industry \& Commerce: R\&D on Jatropha cultivation in Vientiane Province.

h) Biofuel Policy

- established an Ad hoc Committee for Formulation of National Strategy on Biofuel Energy, chaired by the Vice Minister for Energy \& Mines;

- initiated development of a strategy document on biofue and fuel saving opportunities from promoting biofuel production;

- to reflect its potential role in and effect on rural development and to ensure the food security.

5.4. Malaysia [81,83-85]

1. The National Biofuel Policy:

- Launched on 21st March 2006 which envisions:

a) Use of environmental friendly, sustainable and viable sources of energy to reduce the dependency on depleting fossil fuels; and

b) Enhance prosperity and well-being of all the stakeholders agriculture and commodity based industries through stable and remunerative prices.

- Underpinned by 5 Strategic thrusts:

a) Biofuel for transport;

b) Biofuel for industry;

c) Biofuel technologies;

d) Biofuel for export; and

e) Biofuel for cleaner environment.

2. Malaysian Biofuel Industry Act 2007: Act 666

- passed by Parliament in May 2007;

- to facilitate the domestic development of the biodiesel industry;

- provide mandatory use of biofuel, licensing of activities relating to biofuel.

3. National Green Technology Policy (2009): one of the 4 key areas-transportation sector.

4. Cabinet Committee on the Competitiveness of Palm Oil (CCPO) No. 8 (2010):

- biofuel mandatory B5 implementation programmed by region;

- start by phases within Central Region of Peninsular Malaysia (started June 2011); and

- Target nationwide implementation by 2013 onwards.

Recently, government has decided to fully implement B5 biodiesel program nationwide within July 2014. For this palm biodiesel initiative, the PME requirement for the program is estimated at $500,000 t$ per year to support both the subsidized and non-subsidized sectors in Malaysia. To facilitate the program, 35 depots nationwide with in-line blending facilities had been setup by government with help from participating petroleum companies. Subsidy will be provided to ensure B5 price is similar to that of diesel. Biodiesel production increased from 140,983 $t$ in 2012 to $330,032 \mathrm{t}$ in 2013 , of which $155,000 \mathrm{t}$ for domestic use. The jump in production was due to increase in demand for expansion of B5 distribution domestically.

The government also considering the introduction of B7 in 2015, however, currently it is very difficult to predict the speed of implementation. As a result, consumption is predicted to hover between 200,000 and 400,000 t over the next few years. Also, the government is conducting studies to evaluate prospect of B10 and B20 biodiesel program. For B10, government is planning to revise of Malaysian standards, which will include blending up to $10 \%$ PME which is in accordance with Euro 2M specifications. On PME supply, the government has issued 60 biodiesel manufacturing licenses with total yearly capacity of 6.5 million ton as at September, 2013.

\subsection{Myanmar [81]}

1. Bio-energy Policy \& Strategy:

- Energy self-sufficient with particular emphasis on rural area.

- Efficient usage of land and water resources for biomass production balancing food \& fuel production.

- Income generation \& poverty alleviation for rural population through employment opportunity.

- Increasing national income through exporting surplus biofuel \& biomass finished products.

- Promoting private sector participation: small to small \& medium enterprise, both in biomass production \& biofuel processing.

- Development of biofuel industry \& appropriate regulatory measures.

- Government support: loans, credit.

- Promoting private sector including foreign direct investment.

- Providing improved technology through research \& development.

2. Indicative National Biofuel Program

- To reduce dependency on imported fossil fuels.

- To increase economic activities.

- To improve energy efficiency.

- To generate rural employment.

- To augment farmers' income.

3. Indicative National Biofuel Program Framework

- Feedstock Development, Production \& Extension.

- Sugarcane, cassava, sweet sorghum \& Jatropha priotized and other potential feedstocks.

- Biofuel Industry Development.

- Investment, Incentives \& Promotion.

- R\&D.

- Std \& Quality Assurance.

5.6. Philippine $[22,81,86]$

1. RA 9367: Biofuel Acts of 2006

a) Provide fiscal incentives and mandate the use of biofuelblended gasoline and diesel fuels:

- Develop and utilize local based renewable and sustainable clean source energy to reduce dependent on imported oil;

- Mitigate toxic and GHG emissions;

- Improve rural socio-economic; and

- Ensure sustainability of RE.

2. Mandatory use of biofuel

- Biodiesel

- 2007-2009: 1\% (B1) biodiesel blend sold in all gasoline stations.

- 2009-2013: 2\% (B2) biodiesel blend.

\section{Link to Full-Text Articles :}

\section{http://www.sciencedirect.com/science/article/pii/S1364032115001082}


https://ideas.repec.org/a/eee/rensus/v46y2015icp51-61.html

http://umexpert.um.edu.my/file/publication/00003184 119411.pdf

http://ac.els-cdn.com/S1364032115001082/1-s2.0-S1364032115001082- main.pdf? tid=65dd7c72-4010-11e5-

81f0-00000aacb362\&acdnat $=1439287667$ fd1185b2ab9e86b9ec2df5d4a05bd963 